\title{
Article \\ Methane Emissions Regulated by Microbial Community Response to the Addition of Monensin and Fumarate in Different Substrates
}

\author{
Dan Xue ${ }^{1,2, *(\mathbb{D})}$, Huai Chen ${ }^{1,2,3, *}$ and Xiaolin Luo ${ }^{4}$ \\ 1 Key Laboratory of Mountain Ecological Restoration and Bioresource Utilization \& Ecological Restoration \\ Bio-Diversity Conservation, Key Laboratory of Sichuan Province, Chengdu Institute of Biology, \\ Chinese Academy of Sciences, Chengdu 610041, China \\ 2 Zoige Peatland and Global Change Research Station, Chinese Academy of Sciences, Hongyuan 624400, China \\ 3 CAS Center for Excellence in Tibetan Plateau Earth Sciences, Chinese Academy of Sciences, \\ Beijing 100101, China \\ 4 Sichuan Academy of Grassland Sciences, Chengdu 611731, China; LuoxL2004@sina.com \\ * Correspondence: xuedan@cib.ac.cn (D.X.); chenhuai@cib.ac.cn (H.C.)
}

check for updates

Citation: Xue, D.; Chen, H.; Luo, X. Methane Emissions Regulated by Microbial Community Response to the Addition of Monensin and Fumarate in Different Substrates. Appl. Sci. 2021, 11, 6282. https:// doi.org/10.3390/app11146282

Academic Editor: Daniel Cozzolino

Received: 8 May 2021

Accepted: 4 July 2021

Published: 7 July 2021

Publisher's Note: MDPI stays neutral with regard to jurisdictional claims in published maps and institutional affiliations.

Copyright: (C) 2021 by the authors Licensee MDPI, Basel, Switzerland. This article is an open access article distributed under the terms and conditions of the Creative Commons Attribution (CC BY) license (https:/ / creativecommons.org/licenses/by/ $4.0 /)$.
Featured Application: Ruminant livestock contributes significantly to global methane $\left(\mathrm{CH}_{4}\right)$ emissions. The $\mathrm{CH}_{4}$ emissions from ruminants in the Qinghai-Tibet Plateau (QTP) are an important part of China's animal methane emissions. This study evaluated the in vitro effects of $\mathrm{CH}_{4}$ mitigation additives with different mechanisms and their potential interactions with compounds regularly used in yak feed. Basal substrates (forage and vinasse) and methane mitigation additives (monensin sodium salt (MSS) and disodium fumarate (DF)) have interactions with the in vitro rumen fermentation and microbial composition. The different microbial population was critical to the variations in methane production. Comprehensive analyses of rumen microbiome may help further understand the diet-inhibitor interactions in mitigating methane emissions from ruminants in QTP.

Abstract: Ruminants contribute significantly to global methane $\left(\mathrm{CH}_{4}\right)$ emissions. This study aimed to evaluate the in vitro effects of monensin sodium salt (MSS) and disodium fumarate (DF) on $\mathrm{CH}_{4}$ production, rumen fermentation, and microbial community, with different substrates. The addition of MSS and DF, alone and in combination, significantly reduced the concentration and production of $\mathrm{CH}_{4}(p<0.05)$, and while with vinasse as substrate, the $\mathrm{CH}_{4}$ production was higher for forage. The highest propionate production and lowest acetate and propionic ratio (A:P) values were all observed in cultures added to the combination of $14 \mathrm{mmol} / \mathrm{L} \mathrm{DF}$ and $80 \mathrm{mg} / \mathrm{kg}$ MSS in both substrates, suggesting that these additives improved the rumen fermentation efficiency. The diversity indexes of prokaryotic microbiota with forage as the substrate were significantly higher than vinasse, and there were different effects on diversity indexes with the addition of MSS and DF depending on the incubated substrate. Supplementation with MSS and DF increased the number of starch degradation and fumarate reducing bacteria, decreased the number of methanogens, but had no significant effect on the number of fibrolytic bacteria. $\mathrm{pH}, \mathrm{NH}_{3}-\mathrm{N}$, and rumen volatile fatty acids (VFA) were the main factors influencing prokaryotic community structure. In conclusion, basal substrates (forage and vinasse) and $\mathrm{CH}_{4}$ mitigation additives (MSS and DF) have interactions on the in vitro rumen fermentation and microbial composition.

Keywords: monensin; disodium fumarate; in vitro; rumen fermentation; microbial community

\section{Introduction}

Ruminants contribute significantly to global methane $\left(\mathrm{CH}_{4}\right)$ emissions. $\mathrm{CH}_{4}$, a greenhouse gas (GHG), has a major role in climate warming [1]. Agriculture is responsible 
for approximately $40-50 \%$ of global $\mathrm{CH}_{4}$ emissions, with the enteric fermentation $\mathrm{CH}_{4}$ from domestic livestock producing 76-92 Tg/year, accounting for $25 \%$ of anthropogenic methane sources [2,3]. $\mathrm{CH}_{4}$ emissions from domesticated livestock (cattle, sheep, and pigs) in China were 13.21 Tg [4]; however, this data did not include $\mathrm{CH}_{4}$ emissions from yaks. Yaks, as the main domesticated animals on the Qinghai-Tibet Plateau (QTP) in China, are an important source of income for local herdsmen. There are approximately 15 million yak in Chinese territories; this population continues to grow due to the nutritional value of their by-products [5].

Enteric $\mathrm{CH}_{4}$, which results from the fermentation of feed, is primarily emitted from ruminants by eructation. Methanogens in the rumen mainly use $\mathrm{H}_{2}$ to reduce $\mathrm{CO}_{2}$ to $\mathrm{CH}_{4}$. Studies have shown that $\mathrm{H}_{2}$ production management is the most important consideration in reducing $\mathrm{CH}_{4}$ emissions in ruminants [6,7]. There are two main mechanisms to effectively abate $\mathrm{CH}_{4}$ formation this way [8]: the first is to maintain a low $\mathrm{H}_{2}$ pressure by inhibiting $\mathrm{H}_{2}$ liberating reactions. Monensin is an ionophore that can effectively inhibit hydrogen-producing microorganisms (Gram-positive bacteria and protozoa), resulting in more propionate, which means less acetate, formate, butyrate and hydrogen are produced in the rumen $[9,10]$. Monensin has been shown to decrease the methane emissions of rumen $[11,12]$.

A second option is to promote alternative $\mathrm{H}_{2}$-using reactions to compete for the hydrogen used to produce methane. This can be achieved by using propionate enhancers, and other electron acceptors, to decrease $\mathrm{H}_{2}$ availability for $\mathrm{CH}_{4}$ production. Propionate precursors (i.e., fumarate, malate, or acrylate) consume hydrogen generated in the rumen through the succinate fermentation pathway [13]. Fumarate is one of propionate precursors, and fumarate-reducing bacteria use $\mathrm{H}_{2}$ to promote the production of rumen propionate [14]. Newbold et al. (2002) noted that fumarate had the most consistent effects, with 50\% of added acids being fermented to propionate, resulting in a $14 \%$ decrease in methane production [15].

The effects of monensin sodium salt (MSS) or disodium fumarate (DF) on in vitro fermentation and methanogenesis have been comprehensively reported [16-18]. However, few studies have explored the combination effects of these two additives on rumen ecosystem function. MSS and DF have different mechanisms of action for reducing rumen methane emissions; therefore, it was hypothesized that, in combination, rumen methane production would be further decreased, as compared to the use of a single compound.

Here, the effect of supplementation with MSS and DF (alone and in combination) on rumen fermentation, methanogenesis, and the inventory of "microbial types" is reported in vitro. The objective of this work was to study: (a) the effect of MSS and/or DF on rumen fermentation and $\mathrm{CH}_{4}$ production of two different substrates; (b) the relationships between microbial community, ruminal fermentation parameters and $\mathrm{CH}_{4}$ production.

\section{Materials and Methods}

\subsection{Sampling}

Rumen fluid was sampled from six Maiwa yak (age: $4.00 \pm 0.25$ years old; BW: $270.17 \pm 37.27 \mathrm{~kg}$ ). The animals were on a 153 day (19 May 2015 to 28 October 2015) short term fattening trial in Songpan County, Sichuan Province, China. The animal experiment was conducted according to the Regulation of the Administration of Laboratory Animals (2017 Revision) promulgated by Decree No. 676 of the State Council. All procedures of animal care and management followed the National Beef Cattle and Yak Industrial Technical System (CARS-37). The animals were fed twice daily at 8:00 am and 6:00 pm at the livestock shed, and their average daily feed intake was recorded. The average daily intake included $13.08 \pm 0.67 \mathrm{~kg}$ of forage $(\mathrm{F}), 12.98 \pm 0.89 \mathrm{~kg}$ of vinasse $(\mathrm{V})$, and $0.65 \mathrm{~kg}$ of concentrate supplement (Sichuan Tongda Feed Science Application Research Institute). V was fermented with white distiller's grains, corn and wheat bran as solid state fermentation substrates, inoculated with Candida utilis, Aspergillus Niger, Aspergillus oryzae and Bacillus subtilis for $72 \mathrm{~h}$ at $32{ }^{\circ} \mathrm{C}$ and with $45 \%$ moisture. All animals were dewormed 
and immunized in the preliminary feeding period. Sample collection and processing was according to the guidelines of Chengdu Institute of Biology, Chinese Academy of Sciences. The nutritional chemical content of diets and live-weight changes of yaks during the experimental period are shown in Supplementary Materials Table S1. Rumen fluid was collected immediately after slaughtering and filtered through four layers of sterilized gauze into a glass flask and kept under anaerobic conditions by filling it with $\mathrm{N}_{2}$. The glass flask was preserved at $39^{\circ} \mathrm{C}$ and immediately transported to the laboratory.

\subsection{In Vitro Rumen Incubation}

Collected rumen fluid was diluted (1:2) with artificial saliva that had been flushed with $\mathrm{N}_{2}$. The protocol to prepare the artificial rumen inoculum was described by Adesogan et al. [19]. The diluted rumen fluid was maintained under anaerobic conditions, and used as the artificial rumen inoculum. F and $\mathrm{V}$ were used as the substrates for supplementation of MSS and/or DF. The experimental was designed with a $3 \times 3$ factorial arrangement of treatments: T represent treatments with different supplementation, VT represents the different treatments with $\mathrm{V}$ as substrate, and FT represents the different treatments with F as substrate. MSS was supplemented at $0,40,80 \mathrm{mg} / \mathrm{kg}$ (dry matter of substrate); DF was added into serum bottles in vitro, and the final treatment concentrations were 0,7 , and $14 \mathrm{mmol} / \mathrm{L}$ (Table 1). The concentrations of MSS and DF were slightly adjusted according to previous studies $[10,12,14,17]$. Incubation substrate $(450 \mathrm{mg})$ was dispensed into a $100 \mathrm{~mL}$ serum bottle with an appropriate amount of MSS and/or DF, and then $45 \mathrm{~mL}$ artificial rumen inoculum was transferred into each bottle under anaerobic conditions. Inoculated serum bottles (T1-T9; $n=4)$ and non-substrate control (TB; $n=3)$ were sealed with butyl rubber plugs and aluminum caps, and were incubated anaerobically for $24 \mathrm{~h}$ at $39^{\circ} \mathrm{C}$. Gas was collected at 2, 4, 6, 9, 12, 20, and $24 \mathrm{~h}$ using the water displacement method [20], and $1 \mathrm{~mL}$ fermentation gas was simultaneously extracted from the anaerobic serum bottles. The methane content at each time point was measured immediately by gas chromatography. After incubation for $24 \mathrm{~h}$, all samples were cooled on ice to stop the fermentation process, then sampled for DNA extraction, $\mathrm{pH}, \mathrm{NH}_{3}-\mathrm{N}$ and volatile fatty acids (VFA) measurements.

Table 1. Experiment design in vitro.

\begin{tabular}{cccc}
\hline \multirow{2}{*}{ Monensin Sodium Salt $(\mathbf{m g} / \mathbf{k g})$} & \multicolumn{3}{c}{ Disodium Fumarate (mmol/L) } \\
\cline { 2 - 4 } & $\mathbf{0}$ & $\mathbf{7}$ & $\mathbf{1 4}$ \\
\hline 0 & $\mathrm{~T} 1$ & $\mathrm{~T} 2$ & $\mathrm{~T} 3$ \\
40 & $\mathrm{~T} 4$ & $\mathrm{~T} 5$ & $\mathrm{~T} 6$ \\
80 & $\mathrm{~T} 7$ & $\mathrm{~T} 8$ & $\mathrm{~T} 9$ \\
\hline
\end{tabular}

\subsection{Chemical Analyses}

Methane was analyzed using gas chromatography (Agilent 7890A, Agilent Co., Santa Clara, CA, USA). Ruminal fluid $\mathrm{pH}$ was measured using an acidity meter (Sartorius PB10, Göttingen, Germany). $\mathrm{NH}_{3}-\mathrm{N}$ was detected by a continuous flow analyzer (San++, Skalar, Breda, The Netherlands). VFAs were measured using gas chromatography (Agilent 6850, Agilent Co., Santa Clara, CA, USA) with a polar capillary column (HP-FFAP, $30 \mathrm{~m} \times 0.25 \mathrm{~mm} \times 0.25 \mu \mathrm{m}$ ) and a flame ionization detector (FID) [21]. The nutrient contents of $\mathrm{F}$ and $\mathrm{V}$ diets were measured as described previously [22].

\subsection{Microbial Analyses}

\subsection{1. $16 \mathrm{~S}$ rRNA Sequencing}

Total DNA was extracted from $1 \mathrm{~mL}$ fermented rumen fluid by the QIAamp Fast DNA Stool Mini Kit (Qiagen, Hilden, Germany). Universal primers 515F/909R were used for amplification of the V4-V5 hypervariable region of $16 \mathrm{~S}$ rRNA genes. The methods and procedures of MiSeq sequencing and data processing were the same as those described by 
Xue et al. [23]. The sequencing data were deposited in the NCBI Sequence Read Archive, accession number SRP104034.

\subsubsection{Real-Time PCR Analysis}

Eight primer pairs were used to detect populations of selected species in each rumen sample (Table S2). Real-time PCR assays were performed on Chromo 4 (Bio-Rad Laboratories Inc., Hercules, CA, USA) with fluorescence detection by SYBR green dye (Tiangen, Beijing, China). The amplification reactions were performed in a total volume of $20 \mu \mathrm{L}$, containing $1 \mu \mathrm{L}$ dilutions (1:10) of template DNA, $10 \mu \mathrm{L} 2 \times$ SYBR Green SuperReal Premix, $0.6 \mu \mathrm{L}$ of each primer $(10 \mu \mathrm{M})$ and $7.8 \mu \mathrm{L}$ sterilized distilled water. Amplification consisted of one cycle of $95^{\circ} \mathrm{C}(15 \mathrm{~min}), 40$ cycles of denaturation at $95^{\circ} \mathrm{C}(15 \mathrm{~s})$, and annealing/extension at $60^{\circ} \mathrm{C}(1 \mathrm{~min})$. Fluorescence detection was performed after each extension step. For melting curve detection, the temperature was increased by $1{ }^{\circ} \mathrm{C}$ every $30 \mathrm{~s}$ from 60 to $95^{\circ} \mathrm{C}$. The standard curves were generated using 10 -fold dilution series of the linearized plasmid DNA from clones identified as bacteria, methanogenic archaea, ciliate protozoa, anaerobic fungi, Fibrobacter succinogenes, Selenomonas ruminantium, Ruminococcus flavefaciens and Ruminococcus albus. All data were presented as the average copy number of the gene targeted per milliliter of rumen fluid and analyzed using CFX Manager software version 3.1 (Bio-Rad).

\subsection{Data Analysis}

The overall structure of rumen microbiota was assessed by principal coordinate analysis (PCoA). Statistical significance among groups was evaluated by PerMANOVA analysis using "adonis" in the R vegan package [24]. Mantel test and the BioEnv procedure were used to evaluate the relationships between environmental variables and prokaryotic communities, and then selected the environmental variables with the highest Spearman correlation were selected for the variance partitioning analysis (VPA) by "varpart" in the $R$ vegan package. Redundancy analysis (RDA) was performed in Canoco 5, and the significance was tested using the ANOVA procedure in the $\mathrm{R}$ vegan package $(p<0.05)$.

\section{Results}

\subsection{Effect of MSS and DF on In Vitro Rumen Fermentation and Methanogenesis}

The effects of MSS and DF supplementation on in vitro rumen fermentation and methanogenesis are shown in Figure 1 and Table 2. The addition of MSS alone $(40 \mathrm{mg} / \mathrm{kg})$ or DF $(7$ and $14 \mathrm{mmol} / \mathrm{L})$ significantly increased $24 \mathrm{~h}$ total gas production $(p<0.05)$, whereas the addition of only MSS $(80 \mathrm{mg} / \mathrm{kg})$ and the co-addition of MSS and DF caused a linear reduction $(p<0.05)$. The addition of MSS and DF, alone and in combination, was found to significantly decrease methane concentration and production $(p<0.05)$. When $\mathrm{V}$ was the substrate, methane production of was higher than for $\mathrm{F}$; however, the addition of $7 \mathrm{mmol} / \mathrm{L}$ DF and $80 \mathrm{mg} / \mathrm{kg}$ MSS with $V$ as the substrate showed low methane production compared to control cultures $(p<0.01$ ), so did cultures with $\mathrm{F}$ as the substrate (80 mg/kg MSS) $(p<0.05)$. Compared to the control group, MSS and DF supplementation alone or in combination significantly increased propionate production and decreased acetate:propionate $(\mathrm{A}: \mathrm{P})(p<0.05)$. The highest propionate production and lowest A:P values were all observed in cultures supplemented with the combination of $14 \mathrm{mmol} / \mathrm{L} \mathrm{DF}$ and $80 \mathrm{mg} / \mathrm{kg}$ MSS, in both substrates.

\subsection{Effect of MSS and DF Supplementation on Prokaryotic Community Diversity and Structure}

Methane production in different groups was used to analyze the prokaryotic microbial communities under the supplementation of MSS and DF, alone $(14 \mathrm{mmol} / \mathrm{L} \mathrm{DF}$ or $80 \mathrm{mg} / \mathrm{kg}$ MSS) and in combination (7 mmol/L DF and $80 \mathrm{mg} / \mathrm{kg}$ MSS), in both substrates. In total, 182,276 high-quality reads of $16 \mathrm{~S}$ rRNA gene in 28 samples were obtained by MiSeq sequencing; a standard sequence number of 6238 was used to calculate the prokaryotic community characteristics. 
The alpha diversity of prokaryotic microbiota from different groups was calculated (Table S3). The Chao1 index, observed OTUs and Shannon diversity of prokaryotic microbiota with F as the substrate were significantly higher than V $(p<0.05)$. MSS and DF supplementation alone or in combination significantly increased the Shannon diversity and Chao1 index compared to control cultures with $\mathrm{F}$ as the substrate $(p<0.05)$, whereas these values decreased with V $(p<0.05)$. The Chao1 index, observed OTUs and Shannon diversity showed significant positive associations with $\mathrm{pH}, \mathrm{NH}_{3}-\mathrm{N}$, isobutyrate and isovalerate, whereas they had negative associations with butyrate (Table S4). Differences in the prokaryotic community structure under different substrates were evident $\left(R^{2}=0.612\right.$, $p<0.001$ ) based on the weighted UniFrac distance metrics (Figure 2). The first two axes explained $74.61 \%$ of variations (PCo1-axis $64.84 \%$ and PCo2-axis $9.77 \%$ ). Supplementation with MSS and DF had a significant effect on the prokaryotic community structure with V $\left(\mathrm{R}^{2}=0.615, p<0.001\right)$ or $\mathrm{F}\left(\mathrm{R}^{2}=0.472, p<0.001\right)$ as substrate.

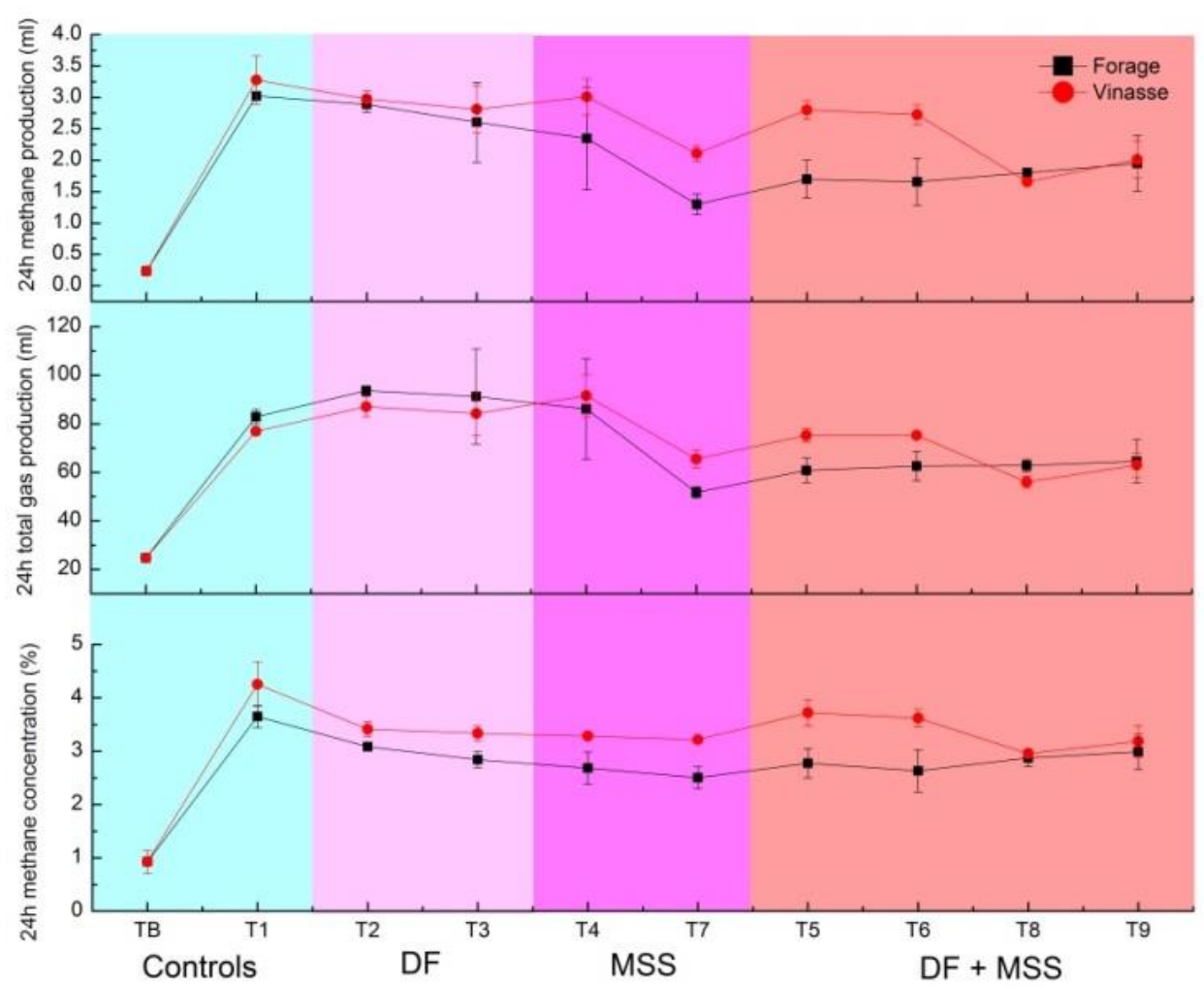

Figure 1. Effect of monensin sodium salt (MSS) and/or disodium fumarate (DF) supplementation on in vitro methanogenesis under different substrates (forage or vinasse). Inoculated bottles with a no-supplementation control (T1) and non-substrate control bottles (TB).

\subsection{Effect of MSS and DF Supplementation on the Composition of Rumen Prokaryotic Community}

The dominant phyla across all samples were Bacteroidetes (average relative abundance 34.14-58.96\%), Firmicutes (6.81-26.89\%), Tenericutes (4.46-40.75\%), Euryarchaeota (2.22-10.12\%) and Spirochaetes (1.30-11.43\%) (Figure 3). Different substrates resulted in variations in the overall prokaryotic community composition. The relative abundances of Euryarchaeota and Tenericutes were significantly influenced by substrate $(p<0.05)$. The relative abundance of Euryarchaeota with $\mathrm{F}$ as substrate increased significantly by $2.91 \%$ compared to V, but Tenericutes was reduced by $28.93 \%(p<0.05)$. Supplementation with MSS and DF, alone and in combination, caused a substantial increase in the relative abundance of Bacteroidetes, Fusobacteria, and Proteobacteria, and decrease in the relative abundance of Euryarchaeota and Firmicutes. 
Table 2. Effect of monensin and fumarate supplementation on the in vitro rumen fermentation under different substrates.

\begin{tabular}{|c|c|c|c|c|c|c|c|c|c|c|}
\hline Parameters & Substrates & T1 & T2 & T3 & $\mathrm{T} 4$ & T5 & T6 & $\mathrm{T} 7$ & $\mathrm{~T} 8$ & T9 \\
\hline \multirow[t]{2}{*}{$\mathrm{pH}$ value } & Forage & $7.35 \pm 0.04 \mathrm{ab}$ & $7.28 \pm 0.08 \mathrm{ab}$ & $7.4 \pm 0.06 \mathrm{a}$ & $7.22 \pm 0.24 \mathrm{ab}$ & $7.41 \pm 0.04 \mathrm{a}$ & $7.39 \pm 0.08 \mathrm{ab}$ & $7.33 \pm 0.12 \mathrm{ab}$ & $7.25 \pm 0.09 \mathrm{~b}$ & $7.35 \pm 0.05 \mathrm{ab}$ \\
\hline & Vinasse & $7.21 \pm 0.00 \mathrm{bc}$ & $7.32 \pm 0.01 \mathrm{a}$ & $7.27 \pm 0.04 \mathrm{ab}$ & $7.17 \pm 0.08 \mathrm{c}$ & $7.24 \pm 0.04 \mathrm{bc}$ & $7.22 \pm 0.06 \mathrm{bc}$ & $7.16 \pm 0.03 \mathrm{~d}$ & $7.25 \pm 0.03 b c$ & $7.23 \pm 0.1 \mathrm{bc}$ \\
\hline \multirow{2}{*}{$\mathrm{NH}_{3}-\mathrm{N}(\mathrm{mg} / \mathrm{dL})$} & Forage & $31.95 \pm 3.07 \mathrm{a}$ & $28.93 \pm 2.31 \mathrm{a}$ & $29.31 \pm 1.99 \mathrm{a}$ & $34.83 \pm 6.78 \mathrm{a}$ & $29 \pm 0.63 \mathrm{a}$ & $28.74 \pm 0.96 \mathrm{a}$ & $26.29 \pm 3.54 \mathrm{a}$ & $36.07 \pm 3.18 \mathrm{a}$ & $31.16 \pm 3.56 \mathrm{a}$ \\
\hline & Vinasse & $22.61 \pm 0.06 \mathrm{a}$ & $17.95 \pm 0.86 \mathrm{c}$ & $20.49 \pm 0.38 \mathrm{~b}$ & $23.05 \pm 1.13 \mathrm{ab}$ & $21.72 \pm 1.2 \mathrm{ab}$ & $23.77 \pm 3.02 \mathrm{ab}$ & $24.93 \pm 1.00 \mathrm{a}$ & $23.41 \pm 0.45 \mathrm{a}$ & $23.31 \pm 1.32 \mathrm{ab}$ \\
\hline \multirow[t]{2}{*}{ Acetate $(\mathrm{mmol} / \mathrm{L})$} & Forage & $36.75 \pm 0.2 \mathrm{a}$ & $38.61 \pm 4.67 \mathrm{a}$ & $41.22 \pm 5.1 \mathrm{a}$ & $44.31 \pm 10.94 \mathrm{a}$ & $34.54 \pm 1.2 \mathrm{a}$ & $36.23 \pm 3.14 \mathrm{a}$ & $30.37 \pm 1.6 \mathrm{a}$ & $37.74 \pm 4.63 \mathrm{a}$ & $38.55 \pm 1.21 \mathrm{a}$ \\
\hline & Vinasse & $33.27 \pm 0.83 \mathrm{abc}$ & $34.67 \pm 2.54 \mathrm{ab}$ & $36.11 \pm 0.85 \mathrm{a}$ & $33.66 \pm 2.27 \mathrm{abc}$ & $37.03 \pm 2.07 \mathrm{a}$ & $32.42 \pm 3.51 \mathrm{abc}$ & $31.35 \pm 2.54 \mathrm{bc}$ & $26.66 \pm 2.47 \mathrm{D}$ & $30.91 \pm 2.39 \mathrm{c}$ \\
\hline \multirow[t]{2}{*}{ Propionate $(\mathrm{mmol} / \mathrm{L})$} & Forage & $8.32 \pm 0.33 b$ & $15.37 \pm 0.89 \mathrm{a}$ & $17.91 \pm 2.43 \mathrm{a}$ & $12.11 \pm 3.71 \mathrm{ab}$ & $13.76 \pm 1.33 \mathrm{ab}$ & $17.91 \pm 0.77 \mathrm{a}$ & $8.45 \pm 0.49 b$ & $14.87 \pm 2.25 \mathrm{ab}$ & $19.82 \pm 2.22 \mathrm{a}$ \\
\hline & Vinasse & $6.32 \pm 0.03 \mathrm{~b}$ & $15.76 \pm 2.86 \mathrm{ab}$ & $14.91 \pm 6.18 \mathrm{ab}$ & $9.58 \pm 1.3 \mathrm{~b}$ & $15.69 \pm 0.27 \mathrm{a}$ & $16.7 \pm 2.65 \mathrm{ab}$ & $10.67 \pm 0.86 \mathrm{~b}$ & $13.11 \pm 2.42 \mathrm{ab}$ & $18.03 \pm 0.98 \mathrm{a}$ \\
\hline \multirow[t]{2}{*}{ Isobutyrate $(\mathrm{mmol} / \mathrm{L})$} & Forage & $0.77 \pm 0.04 \mathrm{a}$ & $0.71 \pm 0.16 \mathrm{a}$ & $0.75 \pm 0.09 \mathrm{a}$ & $0.99 \pm 0.28 \mathrm{a}$ & $0.7 \pm 0.02 \mathrm{a}$ & $0.71 \pm 0.09 \mathrm{a}$ & $0.73 \pm 0.05 \mathrm{a}$ & $0.87 \pm 0.11 \mathrm{a}$ & $0.82 \pm 0.06 \mathrm{a}$ \\
\hline & Vinasse & $0.64 \pm 0.02 \mathrm{ab}$ & $0.60 \pm 0.03 \mathrm{ab}$ & $0.63 \pm 0.05 \mathrm{a}$ & $0.65 \pm 0.02 \mathrm{a}$ & $0.64 \pm 0.02 \mathrm{a}$ & $0.56 \pm 0.06 \mathrm{~b}$ & $0.62 \pm 0.05 \mathrm{ab}$ & $0.56 \pm 0.03 \mathrm{c}$ & $0.59 \pm 0.03 \mathrm{ab}$ \\
\hline Butyrate (mmol/L) & Forage & $6.73 \pm 0.28 \mathrm{ab}$ & $5.65 \pm 1.46 \mathrm{c}$ & $5.97 \pm 0.83 c$ & $9.79 \pm 3.34 \mathrm{a}$ & $6.25 \pm 0.21 b$ & $6.16 \pm 0.92 b$ & $7.27 \pm 0.56 \mathrm{ab}$ & $8.34 \pm 1.24 \mathrm{a}$ & $7.53 \pm 0.61 \mathrm{a}$ \\
\hline \multirow[t]{2}{*}{ Isovalerate $(\mathrm{mmol} / \mathrm{L})$} & Forage & $1.42 \pm 0.06 \mathrm{c}$ & $1.54 \pm 0.17 \mathrm{~b}$ & $1.61 \pm 0.14 \mathrm{~b}$ & $2.05 \pm 0.75 \mathrm{ab}$ & $1.79 \pm 0.24 \mathrm{ab}$ & $1.7 \pm 0.21 \mathrm{ab}$ & $1.63 \pm 0.13 \mathrm{ab}$ & $2.31 \pm 0.24 \mathrm{a}$ & $2.23 \pm 0.39 \mathrm{ab}$ \\
\hline & Vinasse & $1.14 \pm 0.06 \mathrm{c}$ & $1.38 \pm 0.12 \mathrm{ab}$ & $1.42 \pm 0.09 \mathrm{a}$ & $1.15 \pm 0.06 c$ & $1.25 \pm 0.11 \mathrm{bc}$ & $1.11 \pm 0.17 \mathrm{c}$ & $1.1 \pm 0.09 \mathrm{c}$ & $1.05 \pm 0.06 \mathrm{~d}$ & $1.2 \pm 0.12 \mathrm{c}$ \\
\hline \multirow[t]{2}{*}{ Valerate $(\mathrm{mmol} / \mathrm{L})$} & Forage & $1.25 \pm 0.03 \mathrm{ab}$ & $1.13 \pm 0.27 b$ & $1.19 \pm 0.15 \mathrm{ab}$ & $1.65 \pm 0.52 \mathrm{a}$ & $1.14 \pm 0.05 \mathrm{ab}$ & $1.13 \pm 0.16 \mathrm{~b}$ & $1.06 \pm 0.11 \mathrm{c}$ & $1.28 \pm 0.16 \mathrm{ab}$ & $1.24 \pm 0.1 \mathrm{ab}$ \\
\hline & Vinasse & $1.08 \pm 0.03 \mathrm{ab}$ & $1.04 \pm 0.08 \mathrm{~b}$ & $1.05 \pm 0.02 \mathrm{~b}$ & $1.24 \pm 0.13 \mathrm{a}$ & $1.27 \pm 0.07 \mathrm{a}$ & $1.01 \pm 0.13 \mathrm{~b}$ & $1.21 \pm 0.09 \mathrm{a}$ & $0.99 \pm 0.09 \mathrm{~b}$ & $1.14 \pm 0.18 \mathrm{ab}$ \\
\hline \multirow[t]{2}{*}{ Acetate:propionate } & Forage & $4.42 \pm 0.2 \mathrm{a}$ & $2.52 \pm 0.32 \mathrm{ab}$ & $2.31 \pm 0.03 \mathrm{ab}$ & $3.69 \pm 0.23 \mathrm{a}$ & $2.52 \pm 0.18 \mathrm{ab}$ & $2.02 \pm 0.09 \mathrm{ab}$ & $3.59 \pm 0.1 \mathrm{a}$ & $2.55 \pm 0.23 \mathrm{ab}$ & $1.97 \pm 0.27 \mathrm{~b}$ \\
\hline & Vinasse & $5.27 \pm 0.11 \mathrm{a}$ & $2.23 \pm 0.25 \mathrm{ab}$ & $3.01 \pm 1.93 \mathrm{ab}$ & $3.53 \pm 0.23 \mathrm{ab}$ & $2.36 \pm 0.12 \mathrm{ab}$ & $1.95 \pm 0.14 \mathrm{~b}$ & $2.94 \pm 0.04 \mathrm{ab}$ & $2.06 \pm 0.17 b$ & $1.72 \pm 0.06 \mathrm{~b}$ \\
\hline
\end{tabular}




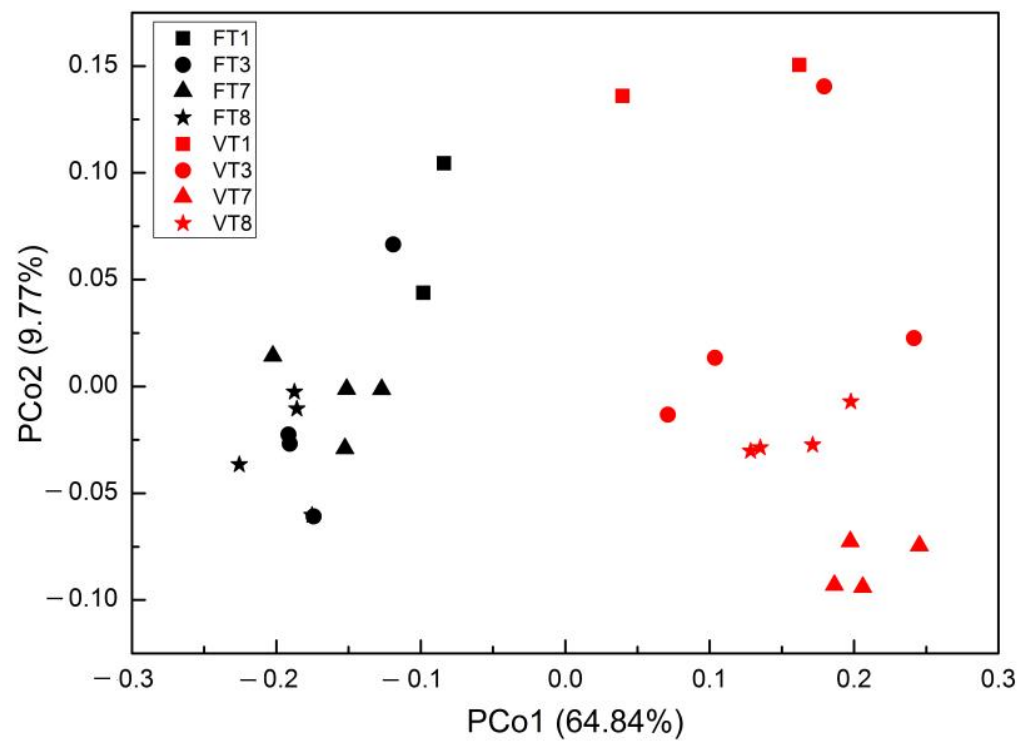

Figure 2. The principal coordinate analysis of prokaryotic communities of $14 \mathrm{mmol} / \mathrm{L}$ disodium fumarate (DF) groups (FT3 and VT3), $80 \mathrm{mg} / \mathrm{kg}$ monensin sodium salt (MSS) groups (FT7 and VT7), $7 \mathrm{mmol} / \mathrm{L} \mathrm{DF}$ and $80 \mathrm{mg} / \mathrm{kg}$ MSS groups (FT8 and VT8), and control groups (FT1 and VT1).

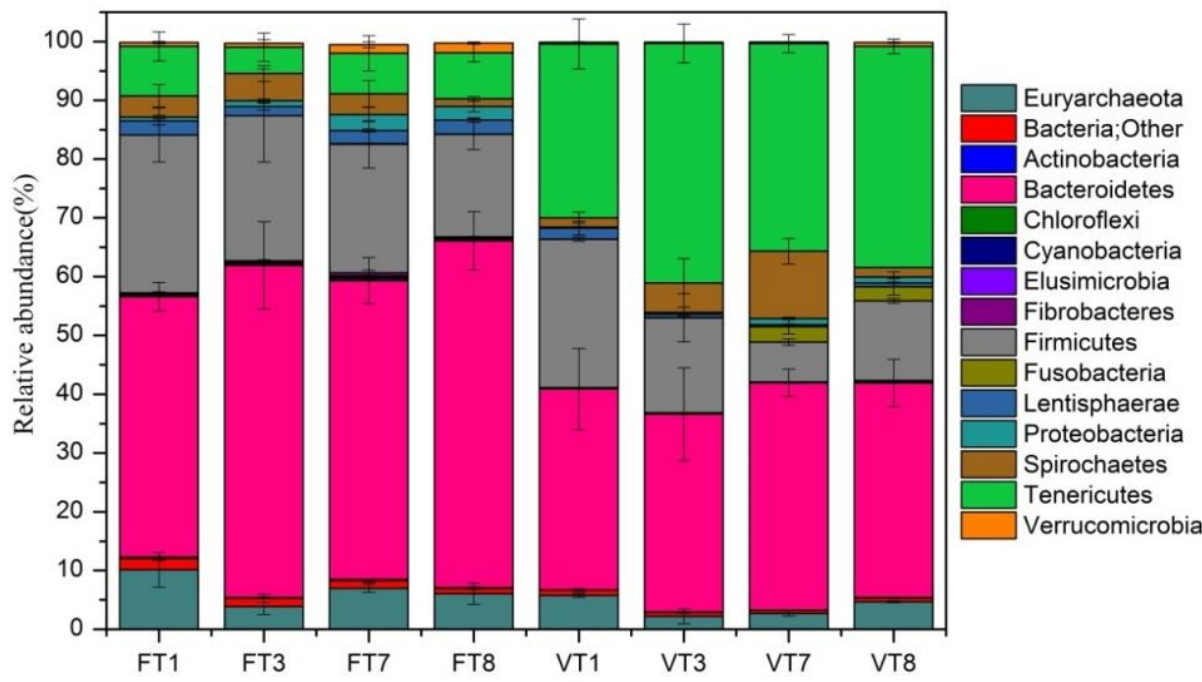

Figure 3. The relative abundance of prokaryotic phyla in $14 \mathrm{mmol} / \mathrm{L}$ disodium fumarate (DF) groups (FT3 and VT3), $80 \mathrm{mg} / \mathrm{kg}$ monensin sodium salt (MSS) groups (FT7 and VT7), $7 \mathrm{mmol} / \mathrm{L} \mathrm{DF}$ and $80 \mathrm{mg} / \mathrm{kg}$ MSS groups (FT8 and VT8), and control groups (FT1 and VT1).

At the genus level, the seven most abundant genera (average relative abundance $>1 \%$ ) included Prevotella (26.34\%), Anaeroplasma (20.37\%), Methanobrevibacter (4.31\%), Treponema (3.30\%), Butyrivibrio (1.41\%) and Succiniclasticum (1.39\%) (Table S5). Methanobrevibacter was the dominant methanogen genus across all samples, which mainly use $\mathrm{H}_{2} / \mathrm{CO}_{2}$ for growth and methanogenesis. The addition of MSS and DF, alone and in combination, increased the relative abundance of Prevotella, Fibrobacter, Selenomonas, Succiniclasticum and Succinivibrio, but decreased the relative abundance of Methanobrevibacter.

\subsection{Relationships between Rumen Fermentation Parameters and Prokaryotic Communities}

An RDA ordination plot was created to explore the relationships between prokaryotic community structure and ruminal fermentation parameters. The results showed that $51.22 \%$ and $12.52 \%$ of the variation in prokaryotic community could be explained by axis 1 and axis 2 (Figure 4); there was a significant correlation between the community structure of 
prokaryotes and rumen fermentation parameters. The Mantel test further showed that there was a significant correlation between rumen fermentation parameters $\left(\mathrm{pH}, \mathrm{NH}_{3}-\mathrm{N}\right.$, acetate, isobutyric, butyrate, and isovaleric) and prokaryotic community structure (Table S6).

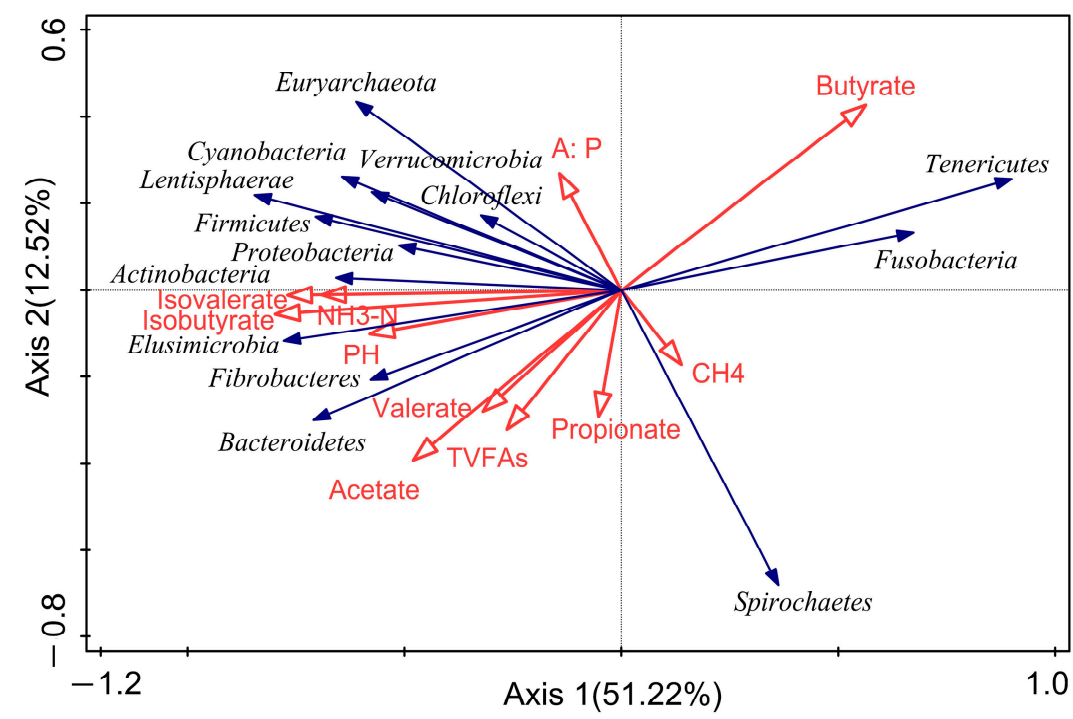

\begin{tabular}{|c|c|c|}
\hline Variable & $\mathrm{F}$ & $p$ \\
\hline $\mathrm{pH}$ & 7.352 & $0.008 * *$ \\
\hline $\mathrm{NH}_{3}-\mathrm{N}$ & 18.212 & $0.001 * * *$ \\
\hline Acetate & 6.1109 & $0.01 * *$ \\
\hline Propionate & 0.5805 & 0.504 \\
\hline Isobutyric & 21.592 & $0.001 * * *$ \\
\hline Butyrate & 12.888 & $0.001 * * *$ \\
\hline Isovaleric & 19.599 & $0.001 * * *$ \\
\hline Valerate & 3.7481 & $0.05 *$ \\
\hline A: P & 1.0342 & 0.34 \\
\hline TVFAs & 1.868 & 0.165 \\
\hline $\mathrm{CH}_{4}$ & 1.2491 & 0.254 \\
\hline
\end{tabular}

Figure 4. Redundancy analysis (RDA) of ruminal fermentation parameters and prokaryotic community compositions at the phylum level. Arrows indicate the direction and magnitude of parameters associated with prokaryotic community structures. A:P, acetate and propionic ratio; TVFAs, total volatile fatty acids.

The VPA showed that $78.3 \%$ of the variation could be explained by three major variables: $\mathrm{pH}, \mathrm{NH}_{3}-\mathrm{N}$, and VFA could independently explain $0.2,1.6$, and $22 \%$ of the total variation. In addition, there were significant interactions among three main variables, such as the interaction of VFAs with $\mathrm{pH}(19 \%)$, VFAs with $\mathrm{NH}_{3}-\mathrm{N}(33.1 \%)$, and three major variables $(2.4 \%)$, were observed (Figure $\mathrm{S} 1$ ). Spearman's correlation analysis found $\mathrm{CH}_{4}$ production were positively correlated with acetate $(p<0.01)$ and TVFAs content $(p<0.05)$ (Table S7). In conclusion, the $\mathrm{pH}, \mathrm{NH}_{3}-\mathrm{N}$ and VFAs were the main factors that influenced prokaryotic community structure.

\subsection{Effect of MSS and DF Supplementation on the Abundance of Selected Microbes}

MSS and DF addition, alone or in combination, significantly increased the population density of F. succinogenes and S. ruminantium compared to control cultures with different substrates $(p<0.05)$ but decreased the population density of methanogenic archaea $(p<0.05)$ (Table 3$)$. The lowest density of methanogens was found in cultures with $14 \mathrm{mmol} / \mathrm{L}$ added DF in F as the substrate, but when V was the substrate, the lowest density of methanogens was found in cultures added with the combination of $7 \mathrm{mmol} / \mathrm{L}$ $\mathrm{DF}$ and $80 \mathrm{mg} / \mathrm{kg}$ MSS. The population density of total bacteria, methanogenic archaea, ciliate protozoa and S. ruminantium with $\mathrm{F}$ as the substrate were lower than $\mathrm{V}$, but the number of fibrolytic bacteria (e.g., R. flavefaciens, F. succinogenes and R. albus) with $\mathrm{F}$ as the substrate were higher than $\mathrm{V}$, demonstrating that $\mathrm{F}$ can provide more material for fibrolytic bacteria growth. 
Table 3. Effect of monensin and fumarate supplementation on selected microbial populations under different substrates.

\begin{tabular}{|c|c|c|c|c|c|c|c|c|}
\hline \multirow{2}{*}{ Target Species } & \multicolumn{4}{|c|}{ Forage } & \multicolumn{4}{|c|}{ Vinasse } \\
\hline & T1 & T3 & T7 & T8 & T1 & T3 & T7 & T8 \\
\hline Total bacteria $\left(\times 10^{7}\right.$ copies $\left./ \mathrm{mL}\right)$ & $3.51 \pm 1.07 \mathrm{abc}$ & $2.54 \pm 1.23 \mathrm{c}$ & $2.83 \pm 1.42 \mathrm{c}$ & $3.34 \pm 2.12 \mathrm{bc}$ & $9.53 \pm 3.22 \mathrm{ab}$ & $10.34 \pm 7.47 \mathrm{a}$ & $9.97 \pm 3.01 \mathrm{a}$ & $5.43 \pm 1.93 \mathrm{abc}$ \\
\hline Methanogenic archaea $\left(\times 10^{5}\right.$ copies $\left./ \mathrm{mL}\right)$ & $2.2 \pm 0.16 \mathrm{bCd}$ & $0.93 \pm 0.42 \mathrm{e}$ & $1.28 \pm 0.63 \mathrm{~d}$ & $1.76 \pm 0.99 \mathrm{Cd}$ & $4.34 \pm 0.44 \mathrm{a}$ & $2.95 \pm 1.74 \mathrm{abc}$ & $3.75 \pm 0.63 \mathrm{ab}$ & $2.63 \pm 0.65 \mathrm{bCd}$ \\
\hline Ciliate protozoa $\left(\times 10^{2}\right.$ copies $\left./ \mathrm{mL}\right)$ & $6.46 \pm 0.22 \mathrm{ab}$ & $2.62 \pm 1.73 \mathrm{~b}$ & $6.36 \pm 4.3 \mathrm{ab}$ & $10.24 \pm 6.21 \mathrm{a}$ & $7.04 \pm 0.71 \mathrm{ab}$ & $9.06 \pm 6.45 \mathrm{ab}$ & $9.9 \pm 2.97 \mathrm{a}$ & $11.25 \pm 5.79 \mathrm{a}$ \\
\hline Anaerobic fungi (copies $/ \mathrm{mL}$ ) & $7.8 \pm 0.48 \mathrm{a}$ & $7.24 \pm 0.91 \mathrm{a}$ & $12.23 \pm 5.47 \mathrm{a}$ & $8.05 \pm 1.42 \mathrm{a}$ & $10.68 \pm 1.47 \mathrm{a}$ & $6.65 \pm 2.99 \mathrm{a}$ & $6.47 \pm 2.08 \mathrm{a}$ & $11.91 \pm 6.39 \mathrm{a}$ \\
\hline Fibrobacter succinogenes $\left(\times 10^{4}\right.$ copies $\left./ \mathrm{mL}\right)$ & $13.89 \pm 6.19 \mathrm{ab}$ & $16.08 \pm 6.27 \mathrm{a}$ & $17.76 \pm 8.31 \mathrm{a}$ & $33.65 \pm 21.54 \mathrm{a}$ & $0.37 \pm 0.09 \mathrm{D}$ & $1.9 \pm 1.48 \mathrm{c}$ & $2.91 \pm 1.03 \mathrm{bc}$ & $1.21 \pm 0.54 \mathrm{c}$ \\
\hline Selenomonas ruminantium $\left(\times 10^{5}\right.$ copies $\left./ \mathrm{mL}\right)$ & $2.15 \pm 0.05 \mathrm{C}$ & $2.43 \pm 0.25 \mathrm{C}$ & $2.75 \pm 0.73 \mathrm{~d}$ & $3.55 \pm 1.8 \mathrm{C}$ & $7.28 \pm 1.73 \mathrm{BC}$ & $15 \pm 8.83 \mathrm{~B}$ & $98.94 \pm 44.96 \mathrm{a}$ & $47.74 \pm 11 \mathrm{aB}$ \\
\hline Ruminococcus flavefaciens $\left(\times 10^{2}\right.$ copies $\left./ \mathrm{mL}\right)$ & $5.74 \pm 0.14 \mathrm{a}$ & $2.08 \pm 0.47 b$ & $2.34 \pm 1.43 \mathrm{~b}$ & $1.85 \pm 0.85 b$ & $1.82 \pm 0.11 b$ & $2.84 \pm 1.19 \mathrm{ab}$ & $2.87 \pm 0.93 \mathrm{ab}$ & $2.09 \pm 0.47 \mathrm{~b}$ \\
\hline Ruminococcus albus $\left(\times 10^{2}\right.$ copies $\left./ \mathrm{mL}\right)$ & $4.63 \pm 0.56 \mathrm{a}$ & $2.42 \pm 0.24 b$ & $1.46 \pm 0.28 \mathrm{C}$ & $1.52 \pm 0.26 \mathrm{C}$ & $0.76 \pm 0.02 \mathrm{~d}$ & $1.46 \pm 0.08 \mathrm{C}$ & $0.34 \pm 0.16 \mathrm{e}$ & $0.50 \pm 0.20 \mathrm{~d}$ \\
\hline
\end{tabular}

Lowercase $p<0.05$ and uppercase $p<0.01$. 


\section{Discussion}

\subsection{Methane Emissions Regulated by Microbial Community under Different Substrates}

Methane production is affected by the substrate, microbial communities, rumen $\mathrm{pH}$, etc. [25]. Different substrates induce different conditions during rumen fermentation. Giraldo et al. [26] found the production of methane was affected by substrates with different forage:concentrate ratios, as 0.3:0.7 (LF) was higher than forage 0.7:0.3 (HF). Serment et al. [27] found that high substrate concentrations produced more $\mathrm{CO}_{2}$ and $\mathrm{CH}_{4}$ than low concentrations. Martinez et al. [28] reported that in vitro methane production was increased by decreasing the forage:concentrate $(\mathrm{F}: \mathrm{C})$ ratio. This study identified that substrate ( $\mathrm{F}$ vs. V) had the most significant impact on methane production. Compared to F substrate, $\mathrm{V}$ had lower NDF and ADF, and higher CP and EE (Table S1), and methane production with $\mathrm{V}$ as the substrate was higher than with $\mathrm{F}$. This may be due to the higher fermentation rates of high-concentrate substrates than those of high-forage ones.

Enteric methane is formed during the microbial degradation of food in the rumen, and any variation in its production level relies on changes in the microbial ecosystem [29]. The diversity indexes of prokaryotic microbiota, with $\mathrm{F}$ as the substrate were significantly higher than V, and the microbial community structure (e.g., Euryarchaeota and Tenericutes) varied under the two substrates. Hook et al. [30] revealed that feeding ruminants a high-concentrate diet changed the diversity and community structure of methanogens but did not affect the abundance of rumen methanogens. Other studies also found that the type of diet can significantly affect the abundance and community of methanogens [31,32], while Patra and Yu (2015) showed that substrate can cause changes in rumen microbial community in vitro fermentation systems, using the denaturing gradient gel electrophoresis (DGGE) profiles of bacterial and archaeal communities [33]. The structure and/or activity of the microbial community determines the methane production and, partially, the utilization of $\mathrm{H}_{2}$ [34]. Manatbay et al. [35] reported that the variable forage:concentrate ratios changed the abundances of cellulolytic bacteria, total fungi and counts of protozoa in the in vitro experiment, however did not change the abundance of methanogens and total bacteria. Consistent with the results of this study, the number of $R$. flavefaciens, F. succinogenes and $R$. albus were higher with $\mathrm{F}$ as substrate than $\mathrm{V}$, but total bacteria, methanogenic archaea, ciliate protozoa and S. ruminantium were lower with $\mathrm{F}$ as substrate than with V. F can provide more material for fibrolytic bacteria growth. Therefore, the variation of rumen methane production may be due to the differences of rumen microbiome caused by different substrates.

\subsection{Effect of Methane Mitigation Additives on In Vitro Methane Production, Rumen Fermentation, and Microbes}

Supplementation with MSS and DF, alone and in combination, enhanced propionate production compared to the control and thus decreased methane production and A:P (Table 2). For all substrates, the mean $\mathrm{CH}_{4}$ production decreased by 6.8 and $14.0 \%$ for concentrations of 7 and $14 \mathrm{mmol} / \mathrm{L} \mathrm{DF}$, respectively, while MSS (40 and $80 \mathrm{mg} / \mathrm{kg}$ ) reduced the methane production by 15.2 and $46.3 \%$, respectively. The effects of MSS and DF on methane production were not consistent. Asanuma et al. [36] reported that supplementation with fumarate to cultures that were fermenting hay powder and concentrate, significantly decreased methane production and increased propionate production. Some studies have also found that the addition of fumarate can decrease methane production during rumen fermentation [37,38]. Lopez et al. [39] reported that fumarate can also be decomposed into acetate stoichiometrically. The addition of fumarate decreased the ratio of acetate:propionate, but increased propionate and acetate production. The acetate production in this study also increased with the addition of DF, but most fumarate in this study could have been converted to propionate. Russell and Houlihan [40] found that monensin can also convert acetate to propionate. Wolin [41] demonstrated a significant correlation between methane production and A:P. Odongo et al. [12] revealed significant declines, of 
7\%, in $\mathrm{CH}_{4}$ emissions from lactating dairy cows fed 60:40 forage-to-concentrate total mixed ratio (TMR) supplemented with monensin.

The addition of MSS and DF also has a significant impact on the rumen microbial community. The addition of MSS and DF decreased the relative abundance of Euryarchaeota and Firmicutes but increased the relative abundance of Bacteroidetes. These were consistent with Abrar et al. [10], who found that monensin inhibits Gram-positive bacteria and protozoa, while reducing the relative abundance of methanogens. Zhou et al. [42] found that the number of methanogens significantly decreased in the rumen fluid samples of sheep fed $20 \mathrm{~g} / \mathrm{kg}$ DF. Methanobrevibacter was the dominant methanogen genus in this study. Janssen and Kirs [43] showed that the number of Methanobrevibacter accounts for nearly two thirds of rumen archaea. Consistent with our previous research result, $\mathrm{H}_{2} / \mathrm{CO}_{2}$ is the main pathway of methanogenesis [23].

S. ruminantium, Veillonella parvula, F. succinogenes, and Wolinella succinogenes are thought to be the major fumarate reducing bacteria in the rumen [36], while R. albus and $R$. flavefaciens are the main celluloytic bacterial species [44]. Fibrolytic bacteria are the main hydrogen production bacteria in rumen fermentation, while fumarate reducing bacteria are the main hydrogen consuming bacteria. Fumarate can stimulate the competition between fumaric acid reducing bacteria and methanogens for hydrogen or formate, and thus reduce the methane production of rumen. The addition of MSS and DF, alone and in combination, increased the number of starch degrading bacteria (Prevotella and Selenomonas) and fumarate reducing bacteria (Fibrobacter and Selenomonas), decreased the number of methanogens, while no significant effect was observed on fibrolytic bacteria $(R$. albus and $R$. flavefaciens). Yang et al. [17] reported that the addition of DF to high-forage diets increased the number of $S$. ruminantium and fumarate-reducing bacteria, but the number of fungi, protozoa, and fibrolytic bacteria were not affected. Asanuma et al. [36] reported the addition of $30 \mathrm{mM}$ fumarate increased the growth of $F$. succinogenes, S. ruminantium, S. lactilytica, $V$. parvula and W. succinogenes in vitro cultures. Giraldo et al. [45] reported no significant impact on the abundance of cellulolytic bacteria by supplementing with fumarate in Rusitec fermenters. Castromontoya et al. [46] found monensin decreased the effectiveness of $\mathrm{H}_{2}$ to $\mathrm{CH}_{4}$ formation, mainly by enhancing the amylolytic activity of inhibiting cellulolytic activity.

\subsection{Interactions between Substrates and Methane Mitigation Additives}

Different substrates may produce different conditions in the rumen, which will further influence how methane inhibitors affect methanogenesis and rumen microbes. The addition of DF was more effective in lowering $\mathrm{CH}_{4}$ production with $\mathrm{V}$ as the substrate, while supplementation with MSS was more effective with F as the substrate. The highest reduction of methane production was $57 \%$, with $80 \mathrm{mg} / \mathrm{kg}$ MSS (T7) with F as the substrate, while the addition of $7 \mathrm{mmol} / \mathrm{L} \mathrm{DF}$ and $80 \mathrm{mg} / \mathrm{kg}$ MSS (T8) with V as the substrate reduced methane production by $49 \%$. Zhang et al. [47] showed that total gas production and $\mathrm{CH}_{4}$ were affected by the interactions between the rare earth element lanthanum and feed mixtures with different levels of NDF. Castromontoya et al. found that "in vitro" methane and VFA production were affected by interactions between feed additives and substrates, but the different microbial populations might be the key to these interaction effects [46]. In this study, the diversity indexes of prokaryotic microbiota with $\mathrm{F}$ as the substrate was significantly higher than $\mathrm{V}$, but had no effect on the diversity indexes with the addition of MSS and DF under different incubated substrates. Additives (DF and MSS) have different mechanisms to alleviate enteric $\mathrm{CH}_{4}$. The effectiveness of these additives is closely related to rumen microbiota. Therefore, a comprehensive analysis of the rumen microbiome can promote the understanding of the interaction between diet and inhibitors in mitigating methane emissions from ruminants in QTP. 


\section{Conclusions}

This study aimed to evaluate the in vitro effects of $\mathrm{CH}_{4}$ mitigation additives with different working mechanisms, and their possible interaction with feed compounds regularly used in yak feed. This study found that the substrate (F vs. V) has the greatest effect on methane production, and the effects of MSS and DF were not consistent. This research provides evidence that basal substrates ( $\mathrm{F}$ and $\mathrm{V}$ ) and methane mitigation additives (MSS and $\mathrm{DF}$ ) have interactions on the in vitro rumen fermentation and the microbial composition. Differences in the microbial population were the key to the variations in methane production. A comprehensive analysis of rumen microbiome may help further understand the diet-inhibitor interactions in mitigating methane emissions from ruminants in QTP.

Supplementary Materials: The following are available online at https:/ /www.mdpi.com/article/10 .3390/app11146282/s1, Figure S1: The relative contributions of ruminal fermentation parameters quantified by variance partitioning analysis (VPA), Table S1: Nutritional chemical contents of diets and live-weight changes of yak during the experimental period, Table S1: Nutritional chemical contents of diets and live-weight changes of yak during the experimental period, Table S2: Primers used for the quantification of rumen microbes by real-time PCR assay, Table S3: Prokaryotic alpha diversity indices at $97 \%$ sequence similarity of $16 \mathrm{~S}$ rRNA gene sequence (per 6238 sequences), Table S4: Spearman correlation coefficients between alpha diversity indices of prokaryotic microbiota and fermentation parameters, Table S5: Relative abundance of dominant prokaryotic groups at the genus levels (values are means \pm standard error), Table S6: Spearman's correlation of fermentation parameters with prokaryotic community structure as determined by the partial Mantel test ${ }^{\text {a }}$, Table S7: Spearman's correlation coefficients between environmental variables.

Author Contributions: D.X.: Conceptualization; software; formal analysis; methodology; validation; writing—original draft preparation; writing—review and editing; H.C.: conceptualization; funding acquisition; writing - review and editing; supervision; X.L.: data curation; formal analysis; writingreview and editing. All authors have read and agreed to the published version of the manuscript.

Funding: This study was funded by Key R\&D Program of Sichuan Province (2020YFS0024), the National Natural Science Foundation of China (42001093) and the Chinese Academy of Sciences Light of West China Program (2018XBZG_XBQNXZ_B_008).

Institutional Review Board Statement: The present study did not involve species that are endangered or protected in China. All procedures of animal care and management followed the National Beef Cattle and Yak Industrial Technical System (CARS-37).

Data Availability Statement: The data presented in this study are available on request from the corresponding author.

Acknowledgments: The authors give special thanks to Wan Xiong for her editing and valuable comments on the manuscript.

Conflicts of Interest: The authors declare that they have no known competing financial interest or personal relationships that could have appeared to influence the work reported in this paper.

\section{References}

1. Lassey, K.R. Livestock methane emission: From the individual grazing animal through national inventories to the global methane cycle. Agric. For. Meteorol. 2007, 142, 120-132. [CrossRef]

2. Chang, J.; Peng, S.; Ciais, P.; Saunois, M.; Dangal, S.R.S.; Herrero, M.; Havlík, P.; Tian, H.; Bousquet, P. Revisiting enteric methane emissions from domestic ruminants and their $\delta 13 \mathrm{CCH} 4$ source signature. Nat. Commun. 2019, 10, 3420. [CrossRef] [PubMed]

3. Denman, K.L.; Brasseur, G.; Chidthaisong, A.; Ciais, P.; Cox, P.M.; Dickinson, R.E.; Hauglustaine, D.; Heinze, C.; Holland, E.; Jacob, D.; et al. Couplings Between Changes in the Climate System and Biogeochemistry. In Climate Change 2007: The Physical Science Basis. Contribution of Working Group I to the Fourth Assessment Report of the Intergovernmental Panel on Climate Change; Solomon, S., Qin, D., Manning, M., Chen, Z., Marquis, M., Averyt, K.B., Tignor, M., Miller, H.L., Eds.; Cambridge University Press: Cambridge, UK; New York, NY, USA, 2007.

4. Mayer, M.; Hyman, R.; Harnisch, J.; Reilly, J.M.; No, T.N. Emissions Inventories and Time Trends for Greenhouse Gases and Other Pollutants; MIT Joint Program on the Science and Policy of Global Change: Cambridge, MA, USA, 2000; p. 49. 
5. $\quad$ Ding, X.Z.; Long, R.J.; Kreuzer, M.; Mi, J.D.; Yang, B. Methane emissions from yak (Bos grunniens) steers grazing or kept indoors and fed diets with varying forage:concentrate ratio during the cold season on the Qinghai-Tibetan Plateau. Anim. Feed Sci. Technol. 2010, 162, 91-98. [CrossRef]

6. Joblin, K.N. Ruminal acetogens and their potential to lower ruminant methane emissions. Crop Pasture Sci. 1999, 50, 1307-1314. [CrossRef]

7. Kahraman, O.; Ozbılgin, A.; Alatas, M.S.; Citil, O.B. Strategies to reduce methane production in ruminants. Sci. Pap. 2015, 58, 144-148.

8. Boadi, D.; Benchaar, C.; Chiquette, J.; Massé, D. Mitigation strategies to reduce enteric methane emissions from dairy cows: Update review. Can J. Anim. Sci. 2004, 84, 319-335. [CrossRef]

9. Hook, S.E.; Northwood, K.S.; Wright, A.D.; Mcbride, B.W. Long-term monensin supplementation does not significantly affect the quantity or diversity of methanogens in the rumen of the lactating dairy cow. Appl. Environ. Microb. 2009, 75, 374-380. [CrossRef]

10. Abrar, A.; Tsukahara, T.; Kondo, M.; Ban-Tokuda, T.; Chao, W.; Matsui, H. Effect of monensin withdrawal on rumen fermentation, methanogenesis and microbial populations in cattle. Anim. Sci. J. 2015, 86, 849-854. [CrossRef]

11. Appuhamy, J.; Strathe, A.B.; Jayasundara, S.; Wagner-Riddle, C.; Dijkstra, J.; France, J.; Kebreab, E. Anti-methanogenic effects of monensin in dairy and beef cattle: A meta-analysis. J. Dairy Sci. 2013, 96, 5161-5173. [CrossRef] [PubMed]

12. Odongo, N.E.; Bagg, R.; Vessie, G.; Dick, P.; Or-Rashid, M.M.; Hook, S.E.; Gray, J.T.; Kebreab, E.; France, J.; McBride, B.W. Long-term effects of feeding monensin on methane production in lactating dairy cows. J. Dairy Sci. 2007, 90, 1781-1788. [CrossRef]

13. McAllister, T.A.; Newbold, C.J. Redirecting rumen fermentation to reduce methanogenesis. Aust. J. Exp. Agric. 2008, 48, 7-13. [CrossRef]

14. Abrar, A.; Kondo, M.; Kitamura, T.; Ban-Tokuda, T.; Matsui, H. Effect of supplementation of rice bran and fumarate alone or in combination on in vitro rumen fermentation, methanogenesis and methanogens. Anim. Sci. J. 2016, 87, 398-404. [CrossRef]

15. Newbold, C.J.; Ouda, J.O.; Lopez, S.; Nelson, N.; Omed, H.; Wallace, R.J.; Moss, A.R. Propionate precursors as possible alternative electron acceptors to methane in ruminal fermentation. In Greenhouse Gases and Animal Agriculture, Proceedings of the 1st International Conference on Greenhouse Gases and Animal Agriculture, Obihiro, Japan, 7-11 November 2001; Elsevier Science BV: Amsterdam, The Netherlands, 2002; pp. 151-154.

16. Shen, J.; Liu, Z.; Yu, Z.; Zhu, W. Monensin and Nisin Affect Rumen Fermentation and Microbiota Differently in vitro. Front. Microbiol. 2017, 8, 1111. [CrossRef] [PubMed]

17. Yang, C.J.; Mao, S.Y.; Long, L.M.; Zhu, W.Y. Effect of disodium fumarate on microbial abundance, ruminal fermentation and methane emission in goats under different forage: Concentrate ratios. Animal 2012, 6, 1788-1794. [CrossRef] [PubMed]

18. Guan, H.; Wittenberg, K.M.; Ominski, K.H.; Krause, D.O. Efficacy of ionophores in cattle diets for mitigation of enteric methane. J. Anim. Sci. 2006, 84, 1896-1906. [CrossRef] [PubMed]

19. Adesogan, A.T.; Krueger, N.K.; Kim, S.C. A novel, wireless, automated system for measuring fermentation gas production kinetics of feeds and its application to feed characterization. Anim. Feed Sci. Technol. 2005, 123, 211-223. [CrossRef]

20. Martínez-Sibaja, A.; Alvarado-Lassman, A.; Astorga-Zaragoza, C.M.; Adam-Medina, M.; Posada-Gómez, R.; Rodríguez-Jarquin, J.P. Volumetric gas meter for laboratory-scale anaerobic bioreactors. Measurement 2011, 44, 1801-1805. [CrossRef]

21. Ishii, S.; Kosaka, T.; Hori, K.; Hotta, Y.; Watanabe, K. Coaggregation facilitates interspecies hydrogen transfer between Pelotomaculum thermopropionicum and Methanothermobacter thermautotrophicus. Appl. Environ. Microbl. 2005, 71, 7838-7845. [CrossRef]

22. Niu, Q.; Li, P.H.; Hao, S.S.; Zhang, Y.Q.; Kim, S.W.; Li, H.Z.; Ma, X.; Gao, S.; He, L.C.; Wu, W.J.; et al. Dynamic Distribution of the Gut Microbiota and the Relationship with Apparent Crude Fiber Digestibility and Growth Stages in Pigs. Sci. Rep. 2015, 5, 9938. [CrossRef]

23. Xue, D.; Chen, H.; Chen, F.; He, Y.; Zhao, C.; Zhu, D.; Zeng, L.; Li, W. Analysis of the rumen bacteria and methanogenic archaea of yak (Bos grunniens) steers grazing on the Qinghai-Tibetan Plateau. Livest. Sci. 2016, 188, 61-71.

24. Warton, D.I.; Wright, S.T.; Wang, Y. Distance-based multivariate analyses confound location and dispersion effects. Methods Ecol. Evol. 2012, 3, 89-101. [CrossRef]

25. Eun, J.S.; Fellner, V.; Gumpertz, M.L. Methane production by mixed ruminal cultures incubated in dual-flow fermentors. J. Dairy Sci. 2004, 87, 112-121. [CrossRef]

26. Giraldo, L.A.; Tejido, M.L.; Ranilla, M.J.; Carro, M.D. Effects of exogenous fibrolytic enzymes on in vitro ruminal fermentation of substrates with different forage: Concentrate ratios. Anim. Feed Sci. Technol. 2008, 141, 306-325. [CrossRef]

27. Serment, A.; Giger-Reverdin, S.; Schmidely, P.; Dhumez, O.; Broudiscou, L.P.; Sauvant, D. In vitro fermentation of total mixed diets differing in concentrate proportion: Relative effects of inocula and substrates. J. Sci. Food Agric. 2016, 96, 160-168. [CrossRef]

28. Martinez, M.E.; Ranilla, M.J.; Tejido, M.L.; Saro, C.; Carro, M.D. The effect of the diet fed to donor sheep on in vitro methane production and ruminal fermentation of diets of variable composition. Anim. Feed Sci. Technol. 2010, 158, 126-135. [CrossRef]

29. Børsting, C.F.; Brask, M.; Hellwing, A.L.F.; Weisbjerg, M.R.; Lund, P. Enteric methane emission and digestion in dairy cows fed wheat or molasses. J. Dairy Sci. 2020, 103, 1448-1462. [CrossRef] [PubMed]

30. Hook, S.E.; Steele, M.A.; Northwood, K.S.; Wright, A.D.; Mcbride, B.W. Impact of high-concentrate feeding and low ruminal pH on methanogens and protozoa in the rumen of dairy cows. Microb. Ecol. 2011, 62, 94. [CrossRef] [PubMed] 
31. Danielsson, R.; Schnürer, A.; Arthurson, V.; Bertilsson, J. Methanogenic population and $\mathrm{CH}_{4}$ production in swedish dairy cows fed different levels of forage. Appl. Environ. Microbl. 2012, 78, 6172. [CrossRef]

32. Zhou, M.; Hernandezsanabria, E.; Guan, L.L. Characterization of variation in rumen methanogenic communities under different dietary and host feed efficiency conditions, as determined by PCR-denaturing gradient gel electrophoresis analysis. Appl. Environ. Microbl. 2010, 76, 3776-3786. [CrossRef] [PubMed]

33. Patra, A.K.; Yu, Z. Effects of garlic oil, nitrate, saponin and their combinations supplemented to different substrates on in vitro fermentation, ruminal methanogenesis, and abundance and diversity of microbial populations. J. Appl. Microbiol. 2015, 119, 127-138. [CrossRef]

34. Popova, M.; Morgavi, D.P.; Doreau, M.; Martin, C. Methane production and ruminal microbial interactions. Prod. Anim. 2011, 24, 447-460.

35. Manatbay, B.; Cheng, Y.F.; Mao, S.Y.; Zhu, W.Y. Effect of Gynosaponin on Rumen In vitro Methanogenesis under Different Forage-Concentrate Ratios. Asian Australas. J. Anim. 2014, 27, 1088-1097. [CrossRef] [PubMed]

36. Asanuma, N.; Iwamoto, M.; Hino, T. Effect of the Addition of Fumarate on Methane Production by Ruminal Microorganisms In Vitro. J. Dairy Sci. 1999, 82, 780-787. [CrossRef]

37. Mamuad, L.; Kim, S.H.; Jeong, C.D.; Choi, Y.J.; Jeon, C.O.; Lee, S.S. Effect of Fumarate Reducing Bacteria on In Vitro Rumen Fermentation, Methane Mitigation and Microbial Diversity. J. Microbiol. 2014, 52, 120-128. [CrossRef]

38. Tejido, M.L.; Ranilla, M.J.; Giraldo, L.A.; Carro, M.D. Influence of disodium fumarate on methane production and microbial activity in Rusitec fermenters fed a mixed diet. J. Anim. Feed Sci. 2007, 16, 609-614. [CrossRef]

39. Lopez, S.; Valdes, C.; Newbold, C.J.; Wallace, R.J. Influence of sodium fumarate addition on rumen fermentation in vitro. Br. J. Nutr. 1999, 81, 59-64. [CrossRef]

40. Russell, J.B.; Houlihan, A.J. Ionophore resistance of ruminal bacteria and its potential impact on human health1. FEMS Microbiol. Rev. 2003, 27, 65-74. [CrossRef]

41. Wolin, M.J. A Theoretical Rumen Fermentation Balance. J. Dairy Sci. 1960, 43, 1452-1459. [CrossRef]

42. Zhou, Y.W.; McSweeney, C.S.; Wang, J.K.; Liu, J.X. Effects of disodium fumarate on ruminal fermentation and microbial communities in sheep fed on high-forage diets. Animal 2012, 6, 815-823. [CrossRef]

43. Janssen, P.H.; Kirs, M. Structure of the archaeal community of the rumen. Appl. Environ. Microbl. 2008, 74, 3619-3625. [CrossRef]

44. Forsberg, C.W.; Cheng, K.J.; White, B.A. Polysaccharide Degradation in the Rumen and Large Intestine. In Gastrointestinal Microbiology; Springer: Boston, MA, USA, 1997.

45. Giraldo, L.A.; Ranilla, M.J.; Tejido, M.L.; Carro, M.D. Influence of exogenous fibrolytic enzymes and fumarate on methane production, microbial growth and fermentation in Rusitec fermenters. Br. J. Nutr. 2007, 98, 753-761. [CrossRef] [PubMed]

46. Castromontoya, J.; De, C.S.; Van, R.G.; Fievez, V. Interactions between methane mitigation additives and basal substrates on in vitro methane and VFA production. Anim. Feed Sci. Technol. 2012, 176, 47-60. [CrossRef]

47. Zhang, T.T.; Zhao, G.Y.; Zheng, W.S.; Niu, W.J.; Wei, C.; Lin, S.X. Effects of rare earth element lanthanum on rumen methane and volatile fatty acid production and microbial flora in vitro. J. Anim. Physiol. Anim. Nutr. 2015, 99, 442-448. [CrossRef] [PubMed] 